\title{
UJI ORGANOLEPTIK PRODUK TEPUNG AMPAS TAHU
}

\author{
Melly Fera*1, Akhmad Solikhin ${ }^{2}$ \\ ${ }^{1,2}$ Program Studi Ilmu dan Teknologi Pangan, Fakultas Sains dan Teknologi Pangan, Universitas \\ Muhadi Setiabudi Brebes

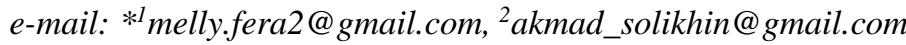

\begin{abstract}
Abstrak
Limbah pangan terutama ampas tahu merupakan salah satu masalah yang perlu mendapat perlakuan serius di Indonesia karena menjadi penyebab berbagai macam masalah lingkungan. Upaya penanganan yang bisa dilakukan salah satunya adalah memanfaatkan limbah ampas tahu menjadi produk tepung. Uji organoleptik digunakan sebagai indikator untuk mengetahui kualitas tepung ampas tahu. Hasil uji organoleptik yang optimal dihasilkan saat dilakukan pengeringan selama 90 menit dengan hasil tidak berbau ampas dan tekstur halus dan tidak menggumpal.
\end{abstract}

Kata kunci: uji organoleptik, limbah pangan, ampas tahu

\section{PENDAHULUAN}

Olahan tahu yang berupa makanan dari bahan baku kedelai yang oleh sebagian masyarakat indonesia menjadi salah satu bahan pangan favorit karena mempunyai nilai ekonomi rendah tetapi secara nilai gizi merupakan sumber protein nabati [1]. Tahu mempunyai kandungan gizi di setiap 100 gram mengandung energi sebesar 86 kkal dan memiliki kandungan protein sebesar 7,8 gram [2]. Akan tetapi dari hasil proses pengolahan tahu akan menghasilkan limbah tahu yang dapat menimbulkan masalah lingkungan apabila langsung dibuang ke lingkungan tanpa melalui proses terlebih dahulu sehingga salah satunya akan muncul berbagai masalah lingkungan salah satunya adalah bau yang tidak sedap. Ampas tahu mempunyai sifat yang mudah berubah baik dari segi bentuk, ketahanannya, dan apabila dijual juga harganya murah. Kebanyakan masyarakat di Indonesia masih memanfaatkan ampas tahu sebagai pakan tambahan ternak dan beberapa diolah menjadi bentuk makanan, padahal secara nilai gizi ampas tahu masih memiliki nilai dan kandungan yang cukup tinggi [3]. Limbah sisa tahu diketahui memiliki kandungan nutrisi yang masih bisa dimanfaatkan bagi manusia dan dapat dimanfaatkan kembali menjadi bahan yang mempunyai nilai lebih. Nilai gizi yang dikandung oleh ampas tahu yaitu protein sebesar 26,6\%, lemak sebesar 18,3\%, karbohidrat sebesar 41,3\%, fosfor sebesar $0,29 \%$, kalsium sebesar 0,19\%, besi sebesar 0,04 persen, dan kandungan air sebesar 0,09\% [4].

Rendahnya tingkat literasi dan informasi terkait dengan pemanfaatan ampas tahu menyebabkan banyak pengrajin tahu membuang begitu saja limbah ampas tahu sehingga dapat berdampak terhadap pencemaran lingkungan. Padahal ampas tahu dapat dimanfaatkan menjadi beberapa produk olahan makanan atau bahan dasar makanan dengan harga jual yang lebih tinggi seperti diolah menjadi kerupuk, tempe gembus, dan tepung. Tepung ampas tahu sudah banyak digunakan sebagai bahan substitusi dalam olahan pangan atau diolah menjadi produk pangan baru dengan rasa yang enak dan aman dikonsumsi seperti kerupuk [5].Ampas tahu memiliki kelemahan mempunyai aroma langu dan mudah mengalami kerusakan dan terjadi proses pembusukan jika tidak cepat ditangani. Salah satu upaya untuk menanggulangi kelemahan ampas tahu tersebut dapat dilakukan alternatif dengan memanfaatkan ampas tahu menjadi produk kering seperti tepung karena secara nilai gizi juga masih tinggi dengan kandungan protein, serat, dan lainnya [6].

Pembuatan tepung ampas tahu membutuhkan ampas tahu yang masih baru dengan beberapa tahapan proses pembuatan seperti pemerasan ampas tahu dengan menggunakan kain

Submitted: Juni 2021, Accepted: Juli 2021, Published: Juli 2021

ISSN: 2775-247x (online), Website: http://jurnal.umus.ac.id/index.php/jtfp 
untuk mengurangi kandungan air, kemudian ampas tahu dikukus selama 15 menit pada suhu $100^{\circ} \mathrm{C}$, setelah proses pengukusan dilakukan dilanjutkan dengan proses penjemuran ampas tahu menggunakan alat pengering atau juga bisa dengan dijemur sampai kering bisa menggunakkan oven atau dengan memanfaatkan energi matahari sampai didapatkan ampas tahu yang kering. Setelah ampas tahu kadar airnya rendah dan teksturnya kering kemudian dilanjutan proses penggilingan untuk mendapatkan tekstur yang halus, setelah itu diayak dengan ukuran 80 mesh [7]. Proses pengeringan sangat dipengaruhi oleh suhu, apabila temperatur yang digunakan dalam prses pengeringan tinggi untuk mengeringkan suatu bahan maka semakin tinggi energi yang disuplai sehingga cepat proses pengeringan terjadi. Ketepatan suhu dan kecepatan waktu saat pengeringan sangat berpengaruh terhadap kualitas tepung, karena pengeringan dengan proses yang terlalu cepat membuat permukaan bahan terlalu kering dapat merusak bahan yang disebabkan karena tidak sebandingnya laju kecepatan uap air yang berpindah ke permukaan bahan [8]. Salah satu metode untuk mengetahui kualitas tepung ampas tahu dengan menggunaan pengujian organoleptik. Pengujian organolepti didasarkan pada prinsip proses penginderaan, pendengaran yang artinya suatu proses yang menitipberatkan pada faktor fisio psikologis yang direspon oleh rangsangan dari sebuah indera terhadap sifat benda[9].

\section{METODE PENELITIAN}

Metode penelitian menggunakan metode uji organoleptik, yaitu pengujian atau penilaian sampel sampel dengan menggunakan indera manusia seperti indera perasa, indera penciuman, indera peraba dan indera penglihatan. Penilaian organoleptik memerlukan beberapa panelis, baik secara perorangan maupun secara kelompok untuk mendapatkan nilai mutu makanan dengan kesan subjektif [10]. Metode Rancangan Acak Lengkap (RAL) ialah metode yang digunakan untuk mendapatkan hasil dengan parameter perlakuan waktu pengeringan yang bervariasi. Parameter uji organoleptik dalam penelitian ini menggunakan 30 panelis yang diambil dari unsur masyarakat dan unsur mahasiswa. Kemudian hasil yang didaptkan dilakukan analisis sidik ragam (ANOVA), dan kemudian apabila hasil diperoleh beda nyata dilanjutkan proses melakukan pengujian DMRT (Duncan's Multiple Range Test)

\section{HASIL DAN PEMBAHASAN}

Uji orgnoleptik menggunakan pendekatan penggunaan indera manusia, sehingga bisa ditentukan parameter uji seperti nilai warna, nilai bau, nilai sebuah rasa, dan nilai dari tekstur.. Warna memiliki nilai yang krusial dalam hal menerima produk pangan dan bisa dipakai untuk menunjukkan sebuah indikasi kualitas terkait baik dan tidaknya sebuah proses pengolahan bahan pangan yang ditandai dengan adanya warna yang merata. Lama pengeringan dianggap sebagai perlakuan yang dijadikan uji indikator warna dengan jumlah perlakuan yang dilakukan sebanyak lima kali dengan variasi waktu percobaan pertama selama lima belas (15) menit, percobaan kedua selama tiga puluh (30) menit, percobaan ketiga selama empat puluh lima (45) menit, percobaan keempat selama enam puluh (60) menit, percobaan kelima selama tujuh puluh lima(75) menit, dan percobaan terakhir selama sembilan puluh (90) menit. Berdasaran analisis menggunakan Anova terhadap lama waktu pengeringan yang dijadikan percobaan diperoleh hasil bahwa memiliki pengaruh yang nyata dengan signifikansi terlihat lebih kecil dari anga 0,005 dan $\mathrm{F}$ hitung yang diperoleh menunjukkan angka 2,27 dengan tingkat kepercayaan 99\%. Dengan diperolehnya hasil tersbut kemudian dilanjutkan dengan melakukan pengujian Duncan's Multiple Range Test sebagai uji lanjut. 
Tabel 1. Hasil Duncan's Multiple Range Test Parameter Warna

\begin{tabular}{ccc}
\hline Percobaan & Nilai Rerata & Kriteria \\
\hline Percobaan 1 & 1,15 & Terlihat warna Coklat Kehitaman \\
Percobaan 2 & 1,31 & Terlihat Warna Coklat Kehitaman \\
Percobaan 3 & 1,82 & Terlihat Warna Coklat Gelap \\
Percobaan 4 & 2,93 & Terlihat Warna Coklat \\
Percobaan 5 & 3,21 & Terlihat Warna Coklat \\
Percobaan 6 & 3,74 & Terlihat Warna Putih Kekuningan \\
\hline
\end{tabular}

Berdasarkan Tabel di atas terlihat pada percobaan 6 dengan lama pengeringan selama 90 menit menghasilkan nilai tertinggi dengan rerata 3,74 dan paling dapat diterima oleh panelis dibandingkan percobaan lainnya karena menghasilkan warna putih kekuningan untuk tepung yang dihasilkan. Waktu pengeringan berpengaruh terhadap hasil warna yang dihasilkan sehingga didapatkan perubahan warna dari tepung ampas tahu.

Lama pengeringan digunakan sebagai perlakuan untuk proses uji organoleptik untuk indikator bau. Pada pengujian bau dilakukan percobaan sebanyak enam kali dengan variasi lama pengeringan. Percobaan dilakukan sebanyak enam kali dengan waktu pengeringan yang berbeda. Waktu pengeringan yang digunakan mempunyai variasi selama lima belas menit, tiga puluh menit, empat puluh lima menit, enam puluh menit, tujuh puluh lima menit, dan sembilan puluh menit. Hasil uji Anova untuk semua percobaan yang dilakukan dalam variasi lama waktu pengeringan tepung ampas tahu diketahui memiliki pengaruh yang nyata dengan nilai signifikansi yang lebih kecil dari 0,005 dan hasil $\mathrm{F}$ hitung sebear 40,25 yang terlihat lebih besar dari $\mathrm{F}$ tabel sebesar 2,27 dengan tingkat kepercayaan sebesar 95\%. Sehingga berdasarkan hasil tersebut diperlukan uji lanjutan menggunaan uji Duncan's Multiple Range Test (DMRT).

Tabel 2. Hasil Duncan's Multiple Range Test Parameter Bau

\begin{tabular}{ccc}
\hline Percobaan & Nilai Rerata & Kriteria \\
\hline Percobaan 1 & 1,29 & Bau Busuk \\
Percobaan 2 & 1,50 & Bau Busuk \\
Percobaan 3 & 2,4 & Bau Tengik \\
Percobaan 4 & 3,2 & Bau Agak Tengik \\
Percobaan 5 & 3,07 & Bau Agak Tengik \\
Percobaan 6 & 3,47 & Tidak Berbau \\
\hline
\end{tabular}

Berdasarkan Tabel 2 di atas terlihat pada percobaan 6 dengan waktu pengeringan selama 90 menit menghasilkan indikator bau dengan hasil tidak berbau. Hal ini dipengaruhi oleh kadar air yang terkandung dalam tepung ampas tahu tersebut sehingga menghasilkan parameter bau yang dapat diterima oleh panelis [11].

Hasil uji Anova untuk percobaan uji organoleptik pada parameter rasa yang dilakukan menunjukkan bahwa nilai signifikansi yang diperoleh masih lebih kecil dari 0,005 dengan $\mathrm{F}$ hitung 93,64 yang nilainya lebih besar dari F tabel sebesar 2,27 dengan tingkat kepercayaan 95\%. Pengujian lanjutan juga diperlukan untuk dilakukan karena berdasarkan hasil Anova semua perlakuan berpengaruh secara nyata. Percobaan juga dilakukan selama enam kali pada parameter rasa ini dengan variasi waktu pengeringan yang sama dengan parameter bau dan warna sebelumnya. Berikut hasil pengujian lanjutan dengan menggunakan Duncan's Multiple Range Test untuk parameter rasa. 
Tabel 3. Hasil Duncan's Multiple Range Test Parameter Rasa

\begin{tabular}{ccc}
\hline Percobaan & Nilai Rerata & Kriteria \\
\hline Percobaan 1 & 1,18 & Tidak ada Khas \\
Percobaan 2 & 1,3 & Tidak ada Khas \\
Percobaan 3 & 1,7 & Sedikit khas ampas tahu \\
Percobaan 4 & 3 & Ada khas ampas tahu \\
Percobaan 5 & 3,3 & Ada khas ampas tahu \\
Percobaan 6 & 3,8 & Banyak khas ampas tahu \\
\hline
\end{tabular}

Berdasarkan hasil Duncan's Multiple Range Test untuk parameter rasa menunjukkan hasil rerata berkisar antara 1,18 sampai dengan 3,8. Hasil denga rerata terbesar yaitu terjadi pada perlakuan waktu pengeringan 90 menit pada percobaan 6 sehingga dapat diterima oleh panelis yang menguji dikarenakan bau yang ditimbulkan tidak melenceng jauh dari bau asli atau bau khas bahan utama yaitu bau tahu.

Tekstur merupakan salah satu indikator yang penting dalam uji organoleptik. Percobaan dengan perlakuan lama waktu pengeringan masih digunaan pada uji ini dengan variasi waktu pada percobaan pertama lima belas menit, percobaan kedua 30 menit, percobaan ketiga empat puluh lima menit, percobaan keempat enam puluh menit, percobaan kelima tujuh puluh lima menit, dan percobaan keenam dilkukan dengan lama pengeringan sembilan puluh menit. Hasil dari uji Anova menunjukkan bahwa semua percobaan dengan perlakuan lama pengeringan mempunyai pengaruh yang nyata dengan nilai signifikansi lebih kecil dari angka 0,005 dan $\mathrm{F}$ hitung yang diperoleh sebesar 101, 67 terlihat lebih besar dari $\mathrm{F}$ tabel yang disyaratkan yaitu 2,27 yang mempunyai tingkat kepercayaan 95\%. Berdasarkan hasil tersebut perlu dilakukan uji lanjutan dengan menggunakan uji Duncan's Multiple Range Test untuk parameter tekstur yang diujicobakan.

Tabel 4. Hasil Duncan's Multiple Range Test Parameter Tekstur

\begin{tabular}{ccc}
\hline Percobaan & Nilai Rerata & Kriteria \\
\hline Percobaan 1 & 1,2 & Menggumpal kasar \\
Percobaan 2 & 1,31 & Menggumpal kasar \\
Percobaan 3 & 1,48 & Sedikit menggumpal, kasar \\
Percobaan 4 & 2,95 & Tidak menggumpal, agak kasar \\
Percobaan 5 & 3,32 & Tidak menggumpal, agak kasar \\
Percobaan 6 & 3,78 & Tidak menggumpal, halus \\
\hline
\end{tabular}

Pengujian lanjutan dengan metode Duncan's Multiple Range Test untuk parameter tekstur dilakukan sebanyak 6 percobaan dengan perbedaan waktu masa pengeringan. Hasil uji dari mulai percobaan pertama sampai dengan percobaan keenam menunjukkan rentang rerata antara 1,2 sampai dengan 3,78. Hal ini dapat dsimpulkan bahwa pada pengujian tekstur diperoleh hasil yang diinginkan dan dapat diterima oleh panelis yang telah ditentukan terlihat pada percobaan 6 dengan nilai rerata 3,78 untuk waktu pengeringan sembilan puluh menit sehingga menghasilkan tekstur untuk tepung ampas tahu tidak menggumpal dan halus.

\section{KESIMPULAN}

Uji organoleptik produk tepung ampas tahu dilakukan dengan melakukan uji untuk parameter warna, rasa, tekstur, dan bau dengan memberikan perlakuan sebanyak enam kali dengan variasai lama pengeringan tepung ampas tahu. Hasil dari semua uji menunjukkan bahwa hasil optimal diperoleh pada waktu pengeringan selama sembilan puluh menit dengan hasil untuk warna terlihat putih kekuningan, tekstur halus tidak ada gumpalan, masih terdapat khas bau ampas limbah tahu, dan tidak berbau sehingga secara mutu sudah bisa dikatakan baik. 


\section{SARAN}

Penelitian uji organoleptik produk tepung ampas tahu mempunyai beberapa saran dan masukan untuk penelitian selanjutnya. Pada penelitian selanjutnya diharapkan menggunakan parameter lain seperti derajat keputihan agar didapatkan kecerahan tepung ampas tahu. Hal lain yang bisa diperhatikan juga terkait dengan variasi suhu yanh bisa ditambahkan lagi serta diperlukan faktor-faktor lain selain proses pengeringan untuk mengetahui karakteristik tepung ampas tahu.

\section{DAFTAR PUSTAKA}

[1] Widaningrum, I, 2015, Teknologi Pembuatan Tahu yang Ramah Lingkungan (Bebas Limbah), Jurnal Fakultas Teknik Universitas Muhammadiyah Ponorogo, Volume 12 Halaman: 14.

[2] Seftiono, H, 2017, Perubahan Sifat Fisika Kimia Protein Selama Proses Pembuatan Tahu Sebagai Rujukan Bagi Posdaya. Jurnal Program Studi Ilmu dan Teknologi Pangan, Univeritas Trilogi, Volume 3 Nomor 1.

[3] Wati, R, 2013, Pengaruh Penggunaan Tepung Ampas Tahu sebagai Bahan Komposit Terhadap Kualitas Kue Kering Lidah Kucing, Food Science and Culinary Education Journal, Volume 2 Nomor 1.

[4] Masyura, M., D, dkk, 2019, Pemanfaatan Limbah Ampas Tahu Dalam Upaya Diversifikasi Pangan, Jurnal Teknologi Pangan dan Hasil Pertanian (AGRITECH), Volume 2, Nomor 2 Juni 2019.

[5] Yustina, I,. Rahmat, F, 2012, Potensi Tepung dari Ampas Industri Pengolahan Kedelai sebagai Bahan Pangan. Prosiding Seminar Nasional: Kedaulatan Pangan dan Energi, Madura, Volume 12 Halaman: 14.

[6] Ridho, R., D, 2012, Pengaruh Substitusi Tepung Ampas Tahu Terhadap Kadar Protein dan Daya Terima Brownies Kukus, Artikel Ilmiah Universitas Muhammadiyah Surakarta.

[7] Fransiska, W., D, 2017, Pengaruh Penggunaaan Tepung Ampas Tahu Terhadap Karakteristik Kimia dan Organoleptik Kue Stick, Jurnal Teknologi Pangan Volume 8 Nomor 2, Hal: 171 -179 .

[8] Fortienawati, M., A, 2015, Modifikasi Dual Solar System Fotovoltaik dan Termal Sebagai Pengering Produk Pangan, Skripsi, Fakultas Pertanian Universitas Sebelas Maret.

[9] Gayatri, M, 2019, Pengaruh Penambahan Buah Kurma (Phoenix dactylifera) Pada Agar-Agar Kombinasi Lidah Buaya (Aloe vera var.chinensis) Terhadap Mutu Organoleptik dan Aktivitas Antioksidan, Skripsi, Program Studi Sarjana Gizi. Stiekes Perintis Padang.

[10] Soekarto, S, 2012, Penilaian Organoleptik. Teknologi Pangan Univeritas Muhammadiyah Semarang, Jakarta: Bharata Kata Aksara.

[11] Cahyani, S, Tamrin, H., 2019, Pengaruh Lama dan Suhu Pengeringan Terhadap Karakteristik Organoleptik, Aktivitas Antioksidan dan andungan Kimia Tepung Kulit Pisang Ambon (Musa Acuminata Colla), Jurnal Sains dan Teknologi Pangan. Universitas Halu Oleo. Volume 4 Nomor 1. 